\title{
Henry R. Rollin
}

\section{In conversation with Alan Kerr}

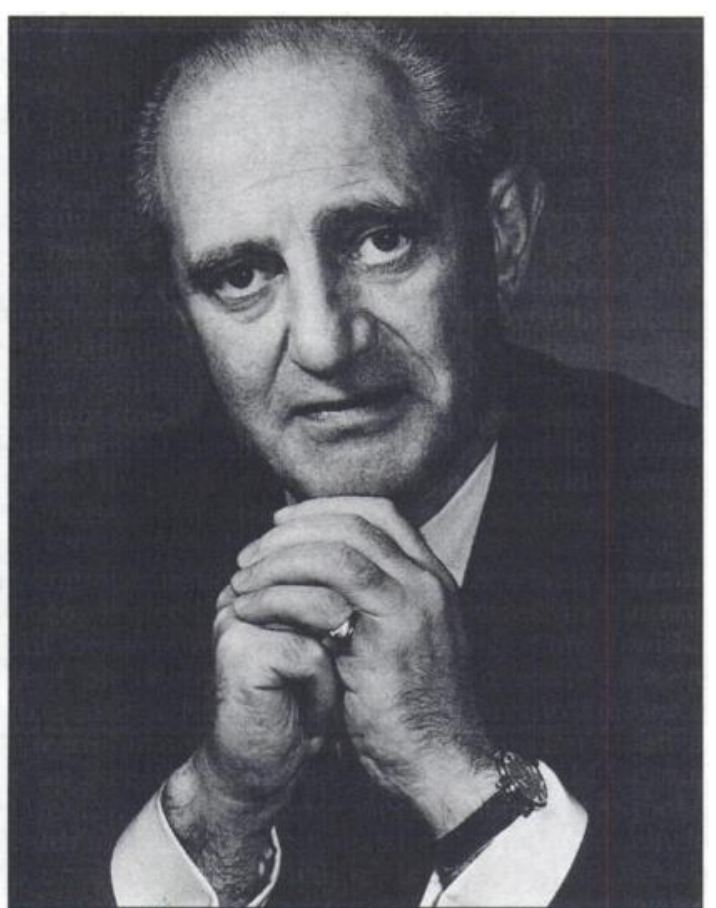

Henry R. Rollin

How did you come into medicine in the first place?

In all honesty, I didn't want to do medicine. I did so, I suppose, in order to fulfil my father's ambition. For myself, I have always wanted to write. I have always respected the integrity of words and have agonised for hours to find le mot juste. As a corollary, I have always been a voracious reader.

You were born in Glasgow?

Yes. Although I was born a Scot I have always considered myself a Yorkshireman. After all, virtually all my conscious memories are of Leeds. I was raised and educated there from primary school until I graduated at the University of Leeds.

So your father encouraged you to go into medicine?

'Encouraged' is probably mild - 'pressured' is a more appropriate term. But, in any event, I
Dr Henry Rapoport Rollin was born in 1911 in Glasgow. He trained in medicine at the University of Leeds, qualifying in 1935. From 1941-1947 he served with the Royal Air Force Voluntary Reserve, rising to the rank of Wing Commander. After obtaining the MD in 1947 he was appointed Deputy Superintendent at Horton Hospital, Epsom, where he remained untll he retired in 1975. He became Fellow of the Royal College of Psychiatrists in 1971, Fellow of the Royal College of Physicians in 1983 and Honorary Fellow of the Royal College of Psychiatrists in 1989. Dr Rollin is the author of three books, more than 50 editorials, innumerable book reviews and an assortment of other literary pieces. He has been active in College affairs for many years. He served as Honorary Librarian from 1975-1985 and in 1987 was appointed to the editorial staff of both the British Journal of Psychiatry and the Psychiatric Bulletin, which functions he still enjoys.

realised that because Latin didn't feature in my matriculation tally of credits, I was not eligible for admission to any of the faculties of art in the University. In the circumstances, I felt, I might as well settle for what I knew would please my parents most, so I agreed.

\section{You went to Leeds Medical School}

Yes, and I hated it. At best I was an indifferent student, not because I was particularly dim, but because I had no interest in anything I was supposed to study. Rote learning, which was largely involved, was anathema to me.

\section{Were there any teachers who impressed you?}

Quite frankly, no. They were a dull, uninspiring lot. It wasn't until I began clinical work that my appetite was whetted. And for this I owe a debt to John Ingram, the distinguished dermatologist, who took an interest in me and invited me to act as his student houseman which I did for several months. For the first time I savoured the drama 
and excitement of working at the 'coal-face' in a large, prestigious hospital that never slept. So keen did I become that I allowed myself the fantasy of specialising in dermatology. However, this would have meant getting higher qualifications, an MD and becoming a Member of the Royal College of Physicians, and considering my dismal academic career thus far, I felt that was a lost cause.

Another reason for unhappiness, peculiar to the Medical School itself was the anything but covert anti-Semitism.

\section{After you got the MB, what did you do?}

My first job was as a house surgeon at Oldham Royal Infirmary, then a down-market hospital, which demanded long hours and hard work for £3 per week plus board and lodging - not a bad salary at that time.

Was there a career plan evolving in your mind at this stage?

Not at all. My overwhelming ambition was to get to London. To begin with, my family had moved from Leeds to London in 1934 and I naturally wanted to be near them. But the other reason was unashamed hedonism: London drew me like a magnet, largely because of the availability of the best theatre, music, opera and ballet as well as the opportunity to enjoy the palpable flavour of a great metropolis as compared with the dull parochialism of, say, Leeds.

Then, after drifting between a variety of locums in hospital and general practice, most of which I hated, I came to the realisation that this kind of vagrancy just had to stop. But what to do? I needed time to think, and it occurred to me that this could be best served by going to sea as a ship's doctor. I had learned from friends that the work was minimal and that it was a glorious opportunity to call on exotic, far-away places visited only thus far in brochures or in my dreams.

In June 1938 I set sail from Birkenhead on the MV Memnon on a voyage lasting six months, calling at ports strung like precious jewels halfway round the world to Japan. It was a superlative experience: I not only succeeded in being bitten irrevocably by the travel bug, but I succeeded also in stiffening my resolution to bring order and structure out of my hitherto haphazard way of life.

On my return, I was as good as my resolve and began to scour the advertisements in the medical press for vacancies. My first attempt was for a job in the medical service of the General Post Office which, mercifully, I failed at interview. Then came an advertisement for vacancies as assistant medical officers (AMOs) in the LCC Mental
Health Service. I had no penchant whatsoever for psychiatry, but it offered a job with career possibilities, so I had a go.

To my surprise, so low had my self-esteem sunk, I was appointed. Even so, I don't think I rated very high in the rank order of those accepted because, I later heard it rumoured, candidates who had scraped through were posted to 'mental deficiency' hospitals. I was posted to Caterham Hospital (later St Lawrence) in Surrey, which was just that!

What was the career structure and atmosphere in mental hospitals in those days?

AMOs who were bachelors, in keeping with some vestige of Victorian morality, were required to live in, even if they weren't on duty, an injunction I chose to ignore on occasion to the wrath of the medical superintendent. There were compensations, however: AMOs lived like renaissance princes: they were fed like fighting cocks and waited on hand and foot in their own quarters by uniformed male servants.

The medical hierarchy was rigid: at the top was a powerful autocrat, the superintendent, on whose grace and favour promotion depended. Then came his deputy, followed by a first AMO, then the second AMO and then as many AMOs - the dogsbodies - as the establishment required.

Promotion, apart from a positive recommendation by the superintendent, depended initially on obtaining the DPM, and only three years were allowed to clear this hurdle. With the diploma, for which the bonus of $£ 50$ was added to your salary, one was eligible for promotion to second AMO. For further promotion, it was almost imperative to acquire a higher qualification, either the MD or Membership of the Royal College of Physicians - or both!

The routine work at the hospital was light. Academically it would have been stagnant, without the determined efforts of the deputy, C. J. C. Earl, a brilliant patrician from Dublin. $\mathrm{He}$ initiated seminars, and was willing to teach anyone wanting to learn: he it was who kickstarted my enthusiasm for anything psychiatric. I became interested in Down's syndrome, just, I suppose, because at the time it was relatively common, and I noted that, in the case of people with Down's syndrome at the lower end of the intellectual scale, their personality characteristics and behaviour departed widely from the original description by Langdon-Down in 1866 , which had been slavishly copied by textbooks. With Earl's encouragement I got to work and eventually converted my research into a thesis which I submitted to Leeds as part of the MD degree. 
You were required to attend courses for a year at the Maudsley to prepare for the DPM

That, in fact, was a tremendous break and a valuable fillip to my interest in psychiatry. The instruction was superb: the teachers, the creme de la crème of British psychiatry, included Aubrey Lewis, Alfred Meyer, Willi Mayer-Gross, Eric Guttman, F. L. Golla and Eliot Slater. For neurology, we had Sam Nevin as a tutor at the Maida Vale Hospital and could attend the teaching at Queen Square which boasted a veritable galaxy of brilliant teachers including Sir Charles Symonds and Dennis Brinton.

You were still at Caterham at the outbreak of war?

Yes. It was there, during the Blitzkrieg that I was to suffer my baptism of fire. From early August to late November, from sunset to dawn, with clockwork precision, the Luftwaffe did their worst - an awful worst - but never enough to break the spirit of London and environs. These included Caterham Hospital, vulnerably situated between the Guards' Depot and RAF Kenley, one of a ring of fighter stations designed to protect London. The former was literally next door to the hospital and the other 1000 yards away.

In 1941, the military situation had so deteriorated that doctors working in London and the periphery who had been hitherto 'frozen' were 'unfrozen'. I seized the opportunity to re-apply for active service and was accepted. I was asked courteously by the War Office Selection Board which service I preferred. Having witnessed with pride and at first-hand the dog-fights fought over my head by our pilots during the Battle of Britain, I unhesitatingly opted for the RAF.

I was posted to Training Command at RAF Little Rissington in the very heart of the Cotswolds. The work, when I became accustomed to the service bureaucracy, was not exacting. But, although this was a training establishment, accidents involving death and serious injury were tragically not infrequent. I suffered for the first time the turmoil of bereavement. What shocked me was how readily I became hardened to the loss of companions with whom I'd shared a meal an hour or two ago. I soon realised it was a protective covering that I'd acquired without which I myself would have become a casualty - a psychiatric casualty. But these near-idyllic conditions came to an end after about six months. For a time I again became an itinerant locum, relieving medical officers within the Command who had fallen sick or were on leave.

In late 1942, however, I was summoned to the Air Ministry to be interviewed by Air Commodore
Burton, the senior 'regular' RAF psychiatrist. His attention had been drawn to the fact that I held the DPM and that it was thought I could be better employed as a neuropsychiatrist. Did I agree? I replied that I not only agreed, but I was delighted. It was in fact a considerable opportunity; the turning point in my career, not only in the RAF, but later in civvy street. I joined the team headed by Air Commodore R. D. Gillespie, the eminent Guy's psychiatrist together with the 'big-wigs' of England's neurologists, Air Vice Marshal Sir Charles Symonds and, further down the pecking order, Dennis Brinton, N. S. (Barney) Alcock and Denis Williams.

I was posted to a WAAF depot to join a team of psychologists and fellow psychiatrists. Our task was to eliminate recruits likely to break down under the stress of service discipline. Later I was transferred to the RAF medical headquarters in London where, inter alia, I was faced with the agonising problem of attempting to differentiate between genuine psychiatric illness and lack of moral fibre'.

\section{You became a Wing Commander?}

Yes. I was honoured and flattered by the promotion, not only because of the prestige, and the pay, but also it taught me the valuable lesson of how to command rather than be commanded.

\section{And after the RAF, what?}

I was contracted to return to the LCC, but I made it clear to the powers-that-be that I would rather resign than return to Caterham, or any equivalent hospital. The RAF had opened up new and infinitely more attractive vistas. That was agreed, and I was posted to Cane Hill near Coulsdon in Surrey.

It was my great fortune to work there under Alexander Walk, who became another of my mentors. He was an incredible scholar. Apart from his linguistic skills, which were formidable, his general knowledge was unbelievable: he could discuss any subject with authority; but he knew what he didn't know - which was very little. I don't have to remind you of his skill as an editor. Encouraged by Walk, I got out the books and set to work in order to complete the MD which I had temporarily abandoned when I enlisted. I passed the exam in 1947 and this success put me in line for promotion. I did not wait long: in early 1948 I was promoted to Deputy Superintendent at Horton Hospital where I remained until I retired in 1975.

I should explain that when I began at Horton, the Emergency Medical Service, which had occupied the hospital during the war, was moving out and we had the job of redesigning 
the hospital as a mental hospital from scratch. This was a mixed blessing: on the positive side, we were able to incorporate all the innovations that had transformed mental hospital from custodial institutions to therapeutic hospitals, or the 'new moral treatment of the insane', as it became called. This was the time when some of the disasters of the era of physical methods were being replaced by the new, exciting era of psychopharmacology.

In 1953 you were elected to a Fulbright Fellowship to study psychosomatic medicine in America?

Yes. I had had a keen interest in the subject and chose to go to Temple University, Philadelphia to sit at the feet of Edward Weiss and Spurgeon English who had written the standard work. As an optional bonus I elected to study for a few weeks at the Phipps Clinic at Johns Hopkins Hospital in Baltimore which, during the reign of the distinguished Adolph Meyer, was the accepted finishing school for British psychiatrists.

\section{American psychiatry was dominated by} psychoanalysis at that time.

Not dominated. Psychoanalysis was psychiatry. I hadn't a clue what the hell anyone was talking about. Early on, at a seminar, I found the discussion so ludicrous that I, most unfortunately, sniggered out loud. I couldn't help it. The chairman was furious, banged the table and exploded, "Henry, it might be a joke to you, but it's a religion to us". And that's what in a nutshell, it was - a religion and the Gospel according to Freud was sacrosanct.

To make a giant leap for a moment. In 1972 I was sent to the USA by the Parole Board to see and report on how they managed parole over there. The transformation was amazing: psychoanalysis was rapidly on the decline and psychopharmacology was on the up. We now had a common language: they called a spade a spade not a phallic symbol - and we got on fine.

You spent the academic year 1963-1964 as a Research Fellow at the Nuffield College, Oxford. How did that come about?

As a result of changes brought about by the Mental Health Act (1959) Horton's catchment area drained far more than our fair share of patients referred from the Courts as mentally abnormal offenders. This created a new phenomenon which prompted my curiosity. I began to collect data, then analyse and work them up. I published papers which came to the attention of Nigel Walker, then Reader in Criminology at Nuffield College. To my surprise and delight, he invited me to Oxford for lunch and to discuss my research. He suggested that I apply for a research fellowship at Nuffield and, after overcoming a number of understandable administrative difficulties at Horton. I did, and in the face of 10 or 12 hopefuls called to interview, I was selected.

It was probably the most fulfilling time in my life. I had time to think, to organise my work and to write it up. Apart from these incalculable blessings, Oxford, particularly Nuffield, gave me the opportunity to sharpen my wits against some of the finest brains in the country.

\section{That year culminated in a book}

Yes, but it wasn't actually published until 1969. It was well received and is widely quoted, even today. It produced a totally unexpected bonus: I was elected Member of the Royal College of Physicians of London in 1976 and in 1983 promoted to Fellow - 48 years (!) after I qualified, giving weight to the appropriateness of the title of my memoirs, Festina Lente - Hasten Slowly.

\section{What happened after you retired from the NHS?}

I had no plans: life seemed suddenly empty. But not for long. A week or two after I retired from the NHS I was approached by the Home Office to work as their Consultant Forensic Psychiatrist. Of course, by that time, I was well known in 'the trade' and my service in the Parole Board from 1970-1974 was also a help. Needless to say, I leapt at the invitation and for the next 10 years I plied my trade, mainly between Brixton Prison and the Central Criminal Court at the Old Bailey.

Let's move on to your College activities. You have been involved in many. I think the first formal one was as Study Tours Secretary.

Yes. I've been a sort of Pooh-Bah. In 1961, when the Tour was in Israel, Edward Stern, the Honorary Secretary, announced, without consultation or permission, that I was to succeed him as secretary. It was a fait accompli and so, as gracefully as I could, I took it on. Over the succeeding years I led tours to Denmark, France and Italy culminating in the World Congress of Psychiatry in Mexico in 1971.

In 1972, I was appointed (or was I elected?) Honorary Librarian which job I held for the statutory 10 years. This was a tough assignment in that there was no library as such at 17 Belgrave Square. There was a collection of books moved from Chandos House in packing cases. An appropriate room, actually where it is presently located, was agreed, but, alas, the architect vetoed the selection until the floor was strengthened to bear the weight of the books. That was done: the floors were lifted and steel girders 
inserted, a time-consuming job. Then purposebuilt bookcases had to be built and the furniture and fittings acquired. A professional librarian, Susan Floate, was appointed and with her help we were in business.

You have been involved with medical writing for a long time

Yes. I suppose this is the way I fulfilled my lifelong desire, or need, to write. I published my first paper in the Journal of Mental Science, the precursor of the British Journal of Psychiatry in 1941, and in the British Medical Journal in 1943. Since then I have published papers fairly regularly in both journals together with a sprinkling of publications in the USA and elsewhere. However, my main contributions have been journalistic. I have written 50 editorials for the British Medical Journal, in addition to many book reviews, letters and a variety of bits-andpieces.

In the 1970 s, I was a regular contributor to World Medicine, probably the most-read and, certainly, the best-loved medical paper in England. It was a sad day when it suddenly and mysteriously folded, not only, I insist because a substantial source of my income was cut-off. I should add that I have contributed chapters to several volumes published by the College, apart from three books I have written as sole author.

Of course, you have been closely involved with the British Journal of Psychiatry and the Psychiatric Bulletin

Well, yes, particularly so in recent years. Hugh Freeman, after his election to the editorship of the British Journal of Psychiatry in 1981, invited me to join the editorial staff as an assistant editor. I undertook the melancholy job of
Obituary Editor; I began the regular monthly column, 'A Hundred Years Ago', and initiated the 'Psychiatric Vignette' column, and I've reviewed books and assessed papers submitted to the British Journal of Psychiatry.

I believe, that you were involved with raising funds to pay for 17 Belgrave Square?

Yes. Way back in 1971, an ad hoc fund-raising committee was formed which included myself, Martin Cuthbert, Wilfred Warren, Martin Roth, Ben Monro, Linford Rees and, importantly, Sir Paul Mallinson from St George's, who managed to combine a successful private psychiatric practice and the chairmanship of his longestablished family business and, by virtue of this, was the only member of the committee familiar with high finance. An expensive professional fund-raising firm was engaged who produced fancy brochures - and that's all! The situation became grave, Sir Paul resigned, because, as I understand it, he feared that the College was in danger of going bankrupt.

However, Martin Roth got to work on his very influential contacts, Lord Goodman and Lord Rayne. My contribution was to appeal to my friend, the late Edward Sieff, then president of Marks \& Spencer, who responded immediately. I will never forget traipsing on a dull, depressing day from Chandos House to Baker Street, Wl, like apprehensive supplicants, to meet the executors of the Miriam Marks' Charitable Trust in the holy-of-holies, the boardroom of Marks \& Spencer. The meeting was eminently successful. We came away with a pledge of $£ 100000$, plus an immediate payment of $£ 5000$ to defray the cost of launching an appeal. Our mood changed and I'm pretty certain that the sun was shining brilliantly when we emerged. 